\title{
PERBANDINGAN SISTEM PERADILAN PIDANA AMERIKA SERIKAT DENGAN PERADILAN PIDANA DI INDONESIA
}

\author{
Oleh: \\ Soediro \\ Fakultas Hukum, Universitas Muhammadiyah Purwokerto \\ E-mail: diro11@gmail.com
}

\begin{abstract}
Abstrak
Sebagaimana tujuan awal pidana yaitu untuk melindungi masyarakat dari tindak pidana, sistem peradilan pidana dibangun untuk menanggulangi masalah kejahatan agar tidak menggangu stabilitas masyarakat. Dengan melihat sistem hukum yang berlaku di negara lain merupakan upaya positif untuk memperbandingkannya dengan sistem hukum yang berlaku di Indonesia. Berdasarkan analisis diperoleh hasil bahwa terdapat perbedaan mendasar dari sistem peradilan pidana di Amerika Serikat dengan di Indonesia yang bersumber dari perbedaan sistem hukum common law dan civil law. Sedangkan pada segi teknis, terdapat perbedaan dari model hukum acara pidana yang berlaku di Amerika Serikat dengan di Indonesia. Selain itu, dari struktur hukum yang ada juga terdapat perbedaan yang signifikan antara Amerika Serikat dengan Indonesia.
\end{abstract}

Kata kunci: Sistem Peradilan Pidana, Due Process Model, Crime Process Model

\section{A. PENDAHULUAN}

Setiap negara mendambakan adanya ketenteraman dan keseimbangan tatanan di dalam masyarakat, yang sekarang lebih populer disebut "stabilitas nasional". Kepentingan manusia baik sebagai individu maupun kelompok, karena selalu terancam oleh bahaya-bahaya di sekelilingnya, memerlukan perlindungan dan harus dilindungi. Kepentingan manusia akan terlindungi apabila masyarakatnya tertib dan masyarakatnya akan tertib apabila terdapat keseimbangan tatanan di dalam masyarakat. Setiap saat keseimbangan tatanan dalam masyarakat dapat terganggu oleh bahaya-bahaya disekelilingnya.

Masyarakat memiliki kepentingan bahwa keseimbangan yang terganggu itu dipulihkan kembali. Salah satu unsur untuk menciptakan atau memulihkan keseimbangan tatanan di dalam masyarakat adalah penegakan hukum atau peradilan yang bebas/mandiri, adil dan konsisten dalam melaksanakan atau 
menerapkan peraturan hukum yang ada dan dalam menghadapi pelanggaran hukum, oleh suatu badan yang mandiri, yaitu pengadilan.1

Kondisi penegakan hukum di Indonesia pada saat ini dinilai dalam keadaan yang tidak menguntungkan. Bahkan, Mahfud M.D menegaskan bahwa proses peradilan tengah berada pada situasi kronis. Hukum yang idealnya memberi rasa keadilan kepada masyarakat malah praktiknya disusupi hegemoni mafia peradilan. Mantan Ketua Mahkamah Konstitusi (MK) tersebut mengatakan kondisi ini menyebabkan mafia peradilan bisa bertindak sesuka hati dalam wilayah hukum di Indonesia. Buktinya, Komisi Pemberantasan Korupsi (KPK) kembali menangkap hakim di Bengkulu. ${ }^{2}$

Sementara itu Mohammadgie berpendapat bahwa ada dua faktor utama mengapa hukum di Indonesiabelum bisa berjalan dengan baik. Pertama, para aparat hukum yang ada belum optimal menjalankan perannya sebagai penegak hukum, terlihat dari kurang diamalkannya etika profesi yang ada oleh aparat hukum tersebut. Faktor yang kedua adalah kurangnya kesadaran dari masyarakat akan pentingnya mentaati hukum, sehingga hukum bisa sesuai dengan fungsinya yaitu mempertahankan ketertiban atau pola kehidupan yang ada, terlihat dari banyaknya pelanggaran-pelanggaran hukum yang dilakukan masyarakat mulai dari hal yang kecil, seperti membuang sampah sembarangan, sampai hal yang besar, seperti penggunaan formalin dalam produksi makanan, peredaran narkoba, dan lain-lain ${ }^{3}$

Pada saat menelaah hukum kita akan menjumpai, bahwa di dalam suatu negara yang tertentu, pada waktu yang tertentu ada berlaku hukum yang tertentu. Hukum yang tertentu, berlaku pada waktu tertentu, di dalam negara tertentu itu biasanya disebut hukum positif. Sehingga dapat dikatakan bahwa hukum positif sumbernya adalah undang-undang, kebiasaan-kebiasaan, dan perjanjianperjanjian ${ }^{4}$

1 http://sudiknoartikel.blogspot.co.id/2008/03/sistem-peradilan-di-indonesia.html, $\quad$ diakses 7 November 2017

2 https://nasional.sindonews.com/read/1111279/13/mahfud-md-bilang-peradilan-di-indonesiakondisi-kronis-1464151938, diakses 7 November 2017.

3 https://mohammadgie.wordpress.com/2011/12/30/lemahnya-penegakan-hukum-diindonesia/diakses tanggal 7 November 2017.

4 R. Soesilo, 1984, Pokok-pokok Hukum Pidana Peraturan Umum dan Delik Khusus, Politea, Bogor, hlm. 2. 
Setiap negara di dunia ini memiliki sistem hukum yang berbeda-beda sesuai yang tercantum dalam statuta yang dirumuskan oleh negara tersebut. Sebagian negara menentukan sendiri sistem hukumnya tanpa dipengaruhi oleh Negara lain. Namun bagi negara-negara bekas jajahan, dimungkinkan menggunakan sistem hukum yang berlaku pada masa penjajahan, sebelum dibentuk hukum yang baru pada negara tersebut. Berdasarkan Teori Negara Hukum, terdapat dua sistem hukum yang umum dikenal, yaitu rechtstaat dan rule of law. Burkens, et.al., mengemukakan pengertian rechtsstaat secara sederhana, yaitu negara yang menempatkan hukum sebagai dasar kekuasaan negara dan penyelenggaraan kekuasaan tersebut dalam segala bentuknya dilakukan di bawah kekuasaan hukum. Pada sistem hukum rechtsstaat, ikatan antara negara dan hukum tidaklah berlangsung dalam ikatan yang lepas atau pun bersifat kebetulan, melainkan ikatan yang hakiki. Sehingga dari pandangan tersebut, mengandung arti bahwa kekuasaan pemerintahan dalam suatu negara bersumber pada hukum dan sebaliknya untuk melaksanakan hukum dalam penyelenggaraan pemerintahan suatu negara harus berdasarkan kekuasaan.

Syarat-syarat dasar rechtsstaat yang dikemukakan oleh Burkens, et.al., yang dikutip oleh Philipus M. Hadjon, adalah sebagai berikut. ${ }^{5}$

1. Asas legalitas; setiap tindak pemerintahan harus didasarkan atas dasar peraturan perundang-undangan (wetterlijke grondslag). Undang-undang dalam arti formal dan UUD sendiri merupakan tumpuan dasar tindak pemerintahan. Sehingga dalam hal ini pembentuk undang-undang merupakan bagian penting negara hukum.

2. Pembagian kekuasaan; syarat ini mengandung makna bahwa kekuasaan negara tidak boleh hanya bertumpu pada satu tangan.

3. Hak-hak dasar (grondrechten); hak-hak dasar merupakan sasaran perlindungan hukum bagi rakyat dan sekaligus membatasi kekuasaan pembentukan undangundang.

4. Pengawasan pengadilan Administrasi; bagi rakyat tersedia saluran melalui pengadilan yang bebas untuk menguji keabsahan tindak pemerintahan (rechtmatigheids toetsing).

5 Philipus M Hadjon, 1994, Ide Negara Hukum dalam Sistem Ketatanegaraan Republik Indonesia, Makalah. 
Sementara itu, The rule of law dalam pengertian ini pada intinya adalah common law sebagai dasar perlindungan bagi kebebasan individu terhadap kesewenang-wenangan oleh penguasa atau dengan kata lain dapat dikatakan bahwa para pejabat negara tidak bebas dari kewajiban untuk mentaati hukum yang mengatur warga negara biasa atau dari yuridiksi peradilan biasa dan menolak kehadiran peradilan administrasi. Sebagai contoh adalah Negara Amerika Serikat. Negara ini memberikan kepercayaan yang tinggi terhadap badan kepolisian, terutama Badan Kepolisian lokal dan Departemen Sheriff sebagai penegak hukum. Sementara kepolisian negara bagian lebih difungsikan untuk memberikan pelayanan yang lebih luas. Lembaga-lembaga federal seperti Biro Investigasi Federal (FBI) dan U.S. Marshals Service memiliki tugas-tugas yang lebih khusus. Ada empat sumber hukum yang berlaku di Amerika Serikat, yaitu hukum konstitusi, hukum administratif, statuta (hukum formal yang tertulis di suatu negara), dan common law (yang mencakup hukum kasus). Keempat sumber hukum tersebut secara sah berlaku sebagai hukum positif dan mengikat kepada seluruh warga masyarakat di negara adidaya tersebut.

Sebagaimana diketahui bahwa Amerika Serikat dan sebagian besar negara Persemakmuran mematuhi traditional common law yang berasal dari sistem hukum negara Inggris, namun hukum Amerika memiliki keunikan dalam beberapa bidang. Hal ini dikarenakan sistem hukum Amerika Serikat tidak lagi terikat kepada sistem hukum Inggris karena terjadinya revolusi kemerdekaan di negara tersebut. Berkembangnya negara Amerika Serikat menjadikannya negara yang mandiri dan melepaskan diri dari sistem hukum Persemakmuran Britania. 6

Indonesia adalah negara yang lebih sekitar 350 tahun dijajah oleh Belanda. Sebagai negara bekas jajahan Belanda, Indonesia terpengaruh oleh hukum yang digunakan oleh Belanda, yang popular dengan istilah civil law atau continental law. Sistem tersebut tentu memiliki perbedaan yang spesifik dengan sistem hukum yang diberlakukan oleh negara yang menganut common law system.

Berdasarkan uraian tersebut di atas maka dapat dikembangkan sebuah penelitian yang membandingkan kedua sistem hukum yang berlaku di Amerika Serikat dan Indonesia. Dengan mengacu kepada pendapat beberapa pakar yang menilai lemahnya penegakan hukum di Indonesia, maka melihat sistem hukum

6 Ibid. 
yang berlaku di negara lain merupakan upaya positif untuk memperbandingkannya dengan sistem hukum yang berlaku di Indonesia. Jika memang sistem hukum yang berlaku di negara lain lebih baik, maka bukan tidak mungkin Indonesia akan menjadikannya sebagai acuan untuk mengadakan perubahan ke arah yang lebih baik. Namun mengingat demikian luasnya lapangan hukum, maka diperlukan penelitian yang komprehensif untuk dapat melakukan penelitian dimaksud. dengan batasan masalah yaitu bagaimana perbandingan sistem peradilan pidana di Amerika Serikat dengan sistem peradilan pidana di Indonesia.

\section{B. PEMBAHASAN}

\section{Pengertian Sistem Peradilan Pidana}

Remington dan Ohlin mengemukakan bahwa criminal justice sytem adalah pendekatan sistem terhadap mekanisme administrasi peradilan pidana, dan peradilan pidana sebagai suatu sistem yang merupakan hasil dari interaksi antara peraturan perundang-undangan, praktik administrasi dan sikap atau tingkah laku sosial. Mardjono memberikan batasan pengertian sistem peradilan pidana adalah sistem dalam suatu masyarakat untuk menanggulangi masalah kejahatan. Menanggulangi di sini diartikan sebagai mengendalikan kejahatan agar berada dalam batas-batas toleransi masyarakat. ${ }^{7}$

\section{Sistem Peradilan Pidana Amerika}

Proses sistem peradilan pidana Amerika dalam garis besarnya memiliki beberapa tahapan sebagai berikut.

a. Tahap sebelum pemeriksaan persidangan
1) Penahanan.
2) Kehadiran di depan Hakim (Initial Appearance).
3) Dengar Pendapat Awal (Preliminary Hearing).
4) Proses Juri Agung (Grand Jury).
5) Pemanggilan Terdakwa (Arraignment).
6) Pernyataan Bersalah (Plea Guilty/ Plea Bargaining).

7 Trisno Raharjo, 2011, Mediasi Pidana dalam Sistem Peradilan Pidana, Mata Padi Pressindo, Yogyakarta, hlm. 3. 
b. Tahap pemeriksaan persidangan
1) Pemilihan Para Juri.
2) Pernyataan Pembuka.
3) Alasan Hukum Jaksa Penuntut.
4) Alasan Hukum Terdakwa/ Kuasa Hukum.
5) Instruksi Juri.
6) Keputusan Juri.

c. Tahap setelah pemeriksaan persidangan
1) Keputusan Hukuman;
2) Permohonan Banding;
3) Eksekusi. ${ }^{8}$

\section{Sistem Peradilan Pidana di Indonesia}

Diundangkannya Undang-undang No 8 Tahun 1981 tentang Kitab Undang-undang Hukum Acara Pidana menjadikan sistem peradilan di Indonesia ini menganut sistem akusator, yaitu pembuktian perkara pidana mengarah kepada pembuktian ilmiah, serta tersangka sebagai pihak pemeriksaan tindak pidana, dan sistem peradilan juga terpengaruh oleh due proses model, yaitu: proses hukum yang adil dan layak serta pengakuan hakhak tersangka/terdakwa. Akan tetapi pelaksanaan peradilan pidana berdasarkan KUHAP ternyata masih belum berjalan lancar, dan masih banyak kelemahan-kelemahan. Due proses model masih jauh dari harapan bahkan pendekatan inkusator masih mendominasi. ${ }^{9}$

Pendekatan sistem peradilan pidana haruslah menyesuaikan dengan karakter masyarakat di mana kejahatan itu terjadi, karena faktor-faktor penyebab terjadinya kejahatan itu sangatlah kompleks. Pada Kongres Perserikatan Bangsa-bangsa Ke-6 Tahun 1980 dalam pertimbangan resolusi mengenai crime trends and crime prevention strategies dinyatakan:

a. bahwa masalah kejahatan merintangi kemajuan untuk mencapai kualitas hidup yang pantas bagi semua orang;

8 Ibid.

9 http://ilmuhukumuin-suka.blogspot.co.id/2013/05/sistem-peradilan-pidanak-di-indonesia.html, diakses pada tanggal 12 September 2017 
b. bahwa strategi pencegahan kejahatan harus didasarkan pada penghapusan sebab-sebab dan kondisi-kondisi yang menimbulkan kejahatan.

c. bahwa penyebab utama dari kejahatan di banyak negara ialah ketimpangan sosial, diskriminasi rasial dan diskriminasi nasional, standar hidup yang rendah, pengangguran dan kebutahurufan (kebodohan) diantara golongan besar penduduk.

\section{Model Hukum Acara Pidana di Amerika}

Menurut Herbert L. Packer di Amerika Serikat berkembang beberapa model dalam rangka penyelenggaraan peradilan pidana. Perlu dijelaskan di sini bahwa penggunaan model di sini bukanlah sesuatu hal yang nampak secara nyata dalam suatu sistem yang dianut oleh suatu negara, akan tetapi merupakan suatu sistem nilai yang dibangun atas dasar pengamatan terhadap praktek peradilan pidana di berbagai negara. Berdasarkan pengamatannya dikatakan bahwa dalam penyelenggaraan peradilan pidana di Amerika Serikat dikenal dua model dalam proses pemeriksaan perkara pidana (two models of the criminal process ) yaitu due process model dan crime control model.

Kedua model di atas, dilandasi oleh adversary model (model perlawanan) yang memiliki ciri-ciri sebagai berikut.

a. Prosedur peradilan harus merupakan suatu disputes atau combating proceeding antara terdakwa dan penuntut umum dalam kedudukan yang sama di muka pengadilan.

b. Judge as umpire dengan konsekuensi bahwa hakim tidak ikut ambil bagian dalam "pertempuran" (fight) dalam proses pemeriksaan di pengadilan. la hanya berfungsi sebagai wasit yang menjaga agar permainan tidak dilanggar, baik oleh terdakwa maupun oleh penuntut umum.

c. Tujuan utama prosedur peradilan pidana adalah menyelesaikan sengketa yang timbul disebabkan terjadinya kejahatan.

d. Para pihak atau kontestan memiliki fungsi yang otonom dan jelas. Peranan penuntut umum adalah melakukan penuntutan, peranan terdakwa adalah menolak atau menyanggah dakwaan. Penuntut umum bertujuan menetapkan fakta mana saja yang akan dibuktikannya disertai bukti yang menunjang fakta tersebut. Terdakwa bertugas menentukan fakta-fakta 
mana saja yang akan diajukan di persidangan yang akan dapat menguntungkan kedudukannya dengan menyampaikan bukti-bukti lain sebagai penunjang fakta tersebut.

Pada crime control model didasarkan pada anggapan bahwa penyelenggaraan peradilan pidana adalah semata-mata untuk menindas perilaku kriminal (criminal conduct), dan ini merupakan tujuan utama proses peradilan, karena yang diutamakan adalah ketertiban umum (public order) dan efisiensi. ${ }^{10}$ Proses kriminal pada dasarnya merupakan suatu perjuangan atau bahkan semacam perang antara dua kepentingan yang tidak dapat dipertemukan kembali yaitu kepentingan negara dan kepentingan individu (terdakwa). Sehingga di sini berlakulah apa yang disebut sebagai "presumption of guilt" (praduga bersalah) dan "sarana cepat" dalam pemberantasan kejahatan demi efisiensi. Akan tetapi dalam praktik model ini mengandung kelemahan yaitu seringnya terjadi pelanggaran hak asasi manusia demi efisiensi. Akibat seringnya terjadi pelanggaran hak asasi manusia maka munculah model yang kedua yang disebut due process model. Due process model memunculkan nilai-nilai baru yang sebelumnya kurang diperhatikan, yaitu konsep perlindungan hak-hak individual dan pembatasan kekuasaan dalam penyelengaraan peradilan pidana. Proses kriminal harus dapat dikendalikan untuk dapat mencegah penyalahgunaan kekuasaan dan sifat otoriter dalam rangka mencapai maksimum efisiensi. Berlaku asas yang sangat penting di dalam model ini yaitu asas praduga tidak bersalah (presumption of innocent).

Kedua model yang diperkenalkan oleh Packer di atas, didasarkan pada pemikiran mengenai hubungan antara negara dan individu dalam proses kriminal yang menempatkan pelaku tindak pidana sebagai musuh masyarakat (enemy of the society), sedangkan tujuan utama dari pemidanaan adalah mengasingkan pelaku tindak pidana dari masyarakat (exile function of punishment). Menurut John Griffiths kedua model tersebut secara filosofis berlandaskan pada model peperangan (battle model) serta pertentangan antara negara dengan individu yang tidak dapat dipertemukan kembali (irreconciliable disharmony of interest) sehingga jika terjadi kejahatan, maka

10 Ansori Sabuan, dkk., 1990, Hukum Acara Pidana, Angkasa, Bandung, hlm. 6. 
terhadap si pelaku harus segera diproses dengan menempatkannya sebagai obyek di dalam sistem peradilan pidana.

Berdasarkan uraian di atas, menurut penulis bahwa crime control model maupun due process model, keduanya tetap berjalan diatas koridor hukum acara, karena keduanya hanyalah kecenderungan model yang ada dalam praktik. Dalam amandemen ke-lima (The Fifth Amendment) konstitusi Amerika, yang merupakan bagian dari Bill of Rights, dinyatakan: No person shall be held to answer for a capital, or otherwise infamous crime, unless on a presentment or indictment of a Grand Jury, except in cases arising in the land or naval forces, or in the Militia, when in actual service in time of War or public danger; nor shall any person be subject for the same offence to be twice put in jeopardy of life or limb; nor shall be compelled in any criminal case to be a witness against himself, nor be deprived of life, liberty, or property, without due process of law; nor shall private property be taken for public use, without just compensation.

\section{Model Hukum Acara di Indonesia}

Pada konsep awalnya perubahan hukum acara dari HIR menjadi KUHAP dilatarbelakangi oleh pemikiran tentang pentingnya perlindungan hak-hak terdakwa dalam proses peradilan pidana, karena tersangka cukup lama tidak memperoleh perlindungan hukum yang layak dan manusiawi. Konsekuensi logis dari perlindungan terhadap hak-hak tersangka atau terdakwa adalah adanya hukum acara yang ketat, sebagai jaminan tidak dilanggarnya hak tersangka maupun terdakwa. Dengan terciptanya KUHAP, maka untuk pertama kalinya di Indonesia diadakan kodifikasi dan unifikasi yang lengkap dalam arti meliputi seluruh proses pidana dari awal (mencari kebenaran) sampai pada kasasi di Mahkamah Agung, bahkan sampai meliputi peninjauan kembali (herziening). ${ }^{11}$ Maka, hukum acara pidana juga merupakan suatu undang-undang yang membatasi tindakan para penguasa dan atau penegak hukum. Perihal batasan ini, sama diakui baik dalam crime control model maupun oleh due process model, di mana terhadap kewenangan penguasa dalam melakukan penyidikan maupun kewenangan penanganan terhadap mereka yang dituduh melakukan tindak pidana, diberikan batasan-batasan

11 Andi Hamzah, 1996, Hukum Acara Pidana di Indonesia, Sapta Artha Jaya, Jakarta, hlm. 3. 
tertentu. Hanya saja, batasan yang tampak dalam crime control model relatif lebih longgar dibandingkan due process model.

Apabila dilihat dari segi asas yang dipakai, KUHAP mengikuti asas 'praduga tak bersalah' (presumption of innocent) - yang biasa dipakai dalam model due process model, bukan asas 'praduga bersalah' (presumption of guilty) - yang biasa dipakai dalam model crime control model. Hal ini tampak dalam Penjelasan KUHAP, Bagian I Umum ke-tiga, yang menyatakan: setiap orang yang disangka, ditangkap, ditahan, dituntut dan atau dihadapkan di muka sidang pengadilan, wajib dianggap tidak bersalah sampai adanya putusan pengadilan yang menyatakan kesalahannya dan memperoleh kekuatan hukum tetap. Selain menunjukkan asas apa yang dipakai oleh KUHAP, penjelasan tersebut juga mengisyaratkan bahwa putusan pengadilan (yang berkekuatan hukum tetap) adalah 'inti' dari proses peradilan, karena penentuan salah atau tidaknya terdakwa sangat tergantung padanya. Asas presumption of innocent adalah asas yang adanya adalah dalam model due process model, dan salah satu ciri khas dari due process model lainnya adalah pentingnya peran pengadilan sebagai tujuan akhir proses dan sebagai tempat untuk menentukan bersalah atau tidaknya terdakwa. Sehingga, bila dilihat dari segi asas yang dipakai dan peran dari pengadilan dalam rangkaian proses peradilan, secara normatif KUHAP cenderung pada model due process model. Hal tersebut adalah bila dilihat dari hukum acara secara umum.

\section{Perbandingan Sistem Peradilan Pidana Indonesia dan Amerika}

Jika dibandingkan, perbedaan mendasar antara Indonesia dan Amerika yang berakibat pada sistem peradilan pidananya adalah terkait tentang sistem hukum dan bentuk negaranya. Indonesia adalah negara berbentuk republik sedangkan Amerika adalah negara serikat. Sudah barang tentu kedua bentuk ini membawa perbedaan mendasar terkait struktur penegak hukum di kedua negara. Terkait lembaga penegak hukumnya, tidak terdapat perbedaan mendasar diantara Indonesia dan Amerika kecuali keberadaan Juri. Selain itu perbedaan mendasar diantara keduanya adalah terkait struktur dan organisasi masing-masing lembaga penegak hukum.

Walaupun Amerika merupakan negara yang memiliki hubungan sejarah dengan Inggris, namun antara Inggris dan Amerika memiliki sistem peradilan 
pidana yang sedikit berbeda. Sistem peradilan pidana di Amerika cukup rumit, tidak ada bentuk baku sistem peradilan pidana di Amerika karena setiap negara bagian memiliki sistem peradilannya masing-masing, walaupun secara garis besar terdapat kesamaan.

a. Kepolisian

Polisi adalah pintu utama atau pintu masuk dalam sistem peradilan pidana Amerika. Polisi pada umumnya adalah pihak pertama yang melakukan kontak dengan seorang tersangka pelaku tindak pidana dan dipaksa untuk membuat sebuah keputusan penting tentang kelanjutan tersangka tersebut. Keputusan paling utama yang dilakukan seorang polisi terhadap tersangka tersebut adalah ketika memutuskan untuk melakukan penangkapan atau tidak yang berakibat pada perjalanan tersangka tersebut untuk menempuh sistem peradilan pidana Amerika. Pada tiap-tiap negara bagian di Amerika, dikenal beberapa macam kepolisian, diantaranya adalah sebagai berikut.

1) Municipal Police (Polisi Kotapraja), berawal dari konsep penjaga malam yang diterapkan di Boston tahun 1636 dan polisi siang di Philadelphia 1833. Pada tahun 1854, antara penjaga malam dan polisi siang digabung dalam sebuah departemen yang berada di bawah seorang Marshal yang dipilih setiap 2 tahun sekali. Berawal dari konsep itulah muncul sebuah kepolisian kotapraja yang berfungsi untuk melindungi kota dan warganya dari kejahatan-kejahatan.

2) State Police (Polisi Negara Bagian), dibandingkan dengan kepolisian kotapraja, kehadiran polisi negara bagian (state police) terbilang baru. Kemunculan lembaga ini dipengaruhi oleh beberapa faktor, diantaranya adalah ketidakefisienan kinerja Polisi Kotapraja serta Departemen Sheriff yang tidak mampu melaksanakan penegakan hukum dengan baik dalam yurisdiksinya.

3) Sherrif Department (Sherrif), departemen sherif ini sudah dikenal jauh sebelum koloni-koloni Inggris datang ke Amerika. Departemen ini merupakan departemen resmi yang memimpin urusan penegakan hukum di kota. Sheriff tidak hanya memimpin urusan penegakan hukum, Sheriff juga merupakan unsur penting dalam pemerintahan kota. Saat ini, Sheriff memiliki tiga tanggung jawab utama, yaitu 
menyelenggarakan layanan penegakan hukum, merawat penjara kota; dan sebagai petugas pengadilan kota.

b. Kejaksaan

Penuntut Umum di Amerika baik yang disebut sebagai State Attorney, District Attorney maupun United States Attorney mewakili pemerintah dalam sistem peradilan pidana di Amerika. Penuntut umum adalah pejabat terpilih atau ditunjuk yang memegang peringkat teratas dalam komunitas penegak hukum. Seringkali penuntut umum bertanggungjawab atas seluruh koordinasi yang berkaitan dengan aktivitas pengadilan pidana mewakili pemerintah. Penuntut Umum memegang peranan yang paling penting dalam sistem peradilan pidana Amerika Serikat.

Kejaksaan berada di bawah kewenangan Departemen Kehakiman Amerika Serikat dan merupakan bagian dari kekuasaan eksekutif yang dipimpin oleh seorang Jaksa Agung (United States Attorney General). Walaupun berada di wilayah eksekutif, namun Kejaksaan bekerja di semua tingkatan proses yudisial, dari pengadilan rendah hingga pengadilan banding negara bagian dan federal yang tertinggi. Kejaksaan di Amerika terdiri dari:

1) Jaksa Penuntut Federal (United States Attorney/ Federal Prosecutor); setiap wilayah yudisial federal memiliki satu jaksa penuntut Amerika Serikat dan satu atau lebih asisten jaksa penuntut Amerika Serikat. Mereka bertanggung jawab untuk menuntut para terdakwa dalam kasus-kasus pidana di pengadilan wilayah federal dan untuk membela Amerika Serikat bila negara ini digugat di suatu pengadilan rendah federal. Sampai saat ini terdapat 93 (sembilan puluh tiga) kantor jaksa penuntut Amerika Serikat yang berada di 50 negara bagian Amerika Serikat, District of Columbia, Guam, Northern Mariana Islands, Puerto Rico dan Virgin Islands. Masing-masing jaksa penuntut Amerika Serikat adalah kepala penegakan hukum wilayah federal dan membawahi kantor-kantor jaksa wilayah.

2) Jaksa Penuntut Negara Bagian (State Attorney/ District Attorney); atau dikenal juga sebagai jaksa penuntut wilayah adalah mereka yang menuntut orang-orang yang didakwa melanggar undang-undang pidana negara bagian. Pada sebagian besar negara bagian, jaksa penuntut 
wilayah dipilih oleh pejabat daerah, namun di beberapa negara bagian lainnya mereka diangkat. Kantor kejaksaan wilayah memiliki banyak kekuasaan dalam menangani perkara-perkara, termasuk untuk tidak membawa perkara ke pengadilan. Tidak semua perkara diterima untuk disidangkan di pengadilan, beberapa ditolak, yang lainnya tidak dituntut. Namun, sebagian besar perkara tergantung pada tawar menawar pernyataan bersalah (plea bargaining) sehingga perkara diputus lebih ringan atau meniadakan beberapa dakwaan

3) Jaksa Agung Negara Bagian; masing-masing negara bagian memiliki seorang jaksa agung yang berfungsi sebagai pejabat hukum utama. Pada sebagian besar negara bagian pejabat ini dipilih berdasarkan suara pendukung di seluruh negara bagian. Walaupun tuntutan terhadap terdakwa umumnya dilakukan oleh jaksa wilayah setempat, namun kantor kejaksaan agung sering memainkan peranan penting dalam menyidik tindak pidana di seluruh negara bagian. Sehingga dengan demikian, jaksa agung dan stafnya dapat bekerja erat dengan jaksa penuntut wilayah dalam menyiapkan suatu perkara tertentu.

c. Pengadilan

Salah satu ciri yang paling penting, paling menarik dan paling membingungkan dalam sistem peradilan Amerika Serikat adalah sistem pengadilan ganda, yaitu setiap tingkat pemerintahan (negara bagian dan nasional) memiliki kumpulan pengadilannya sendiri. Beberapa masalah hukum dipecahkan sepenuhnya di pengadilan negara bagian, sementara yang lain ditangani oleh pengadilan federal. Meskipun demikian, masalahmasalah lain mungkin mendapatkan perhatian dari kedua pengadilan, yang terkadang dapat menimbulkan friksi.

Baik pengadilan negara bagian maupun pengadilan federal berpusat di Mahkamah Agung sebagai struktur tertinggi dalam pengadilan. Setidaknya, ada tiga kelompok pengadilan di Amerika, yaitu:

1) Pengadilan negara bagian; tidak ada dua negara bagian yang benarbenar serupa dalam hal organisasi pengadilan. Setiap negara bagian bebas untuk mengadopsi skema organisasi tertentu yang dipilihnya, menciptakan sebanyak mungkin pengadilan yang diinginkannya, 
menamakan pengadilan dengan apapun yang disukainya dan menetapkan yurisdiksi sebagaimana yang dianggap cocok. Beberapa negara bagian telah membentuk sistem pengadilan yang bersatu, sementara yang lain masih beroperasi dengan jumlah pengadilan yang membingungkan dengan yurisdiksi yang tumpang tindih Pengadilanpengadilan negara bagian dapat dibagi ke dalam empat kategori umum yang menunjukkan jenjang pengadilan, yaitu:

a) pengadilan rendah dengan yurisdiksi terbatas;

b) pengadilan rendah dengan yurisdiksi umum;

c) pengadilan banding menengah; dan

d) pengadilan akhir (court of last resort).

2) Pengadilan negara federal, pengadilan federal Amerika Serikat memiliki sejarah panjang, dan seiring dengan perkembangan kemerdekaan Amerika Serikat. Pengadilan negara federal terdiri dari dua pengadilan yaitu:

a) Pengadilan Distrik Amerika Serikat; merupakan dasar bagi sistem hukum federal. Pengadilan distrik memiliki fungsi sebagai penegak norma, sementara pengadilan banding dipandang memiliki kesempatan untuk membuat kebijakan. Penegakan norma terkait secara erat dengan administrasi keadilan, karena semua bangsa mengembangkan standar-standar yang dianggap penting bagi suatu masyarakat yang adil dan teratur. Seorang hakim yang memutus perkara berkaitan dengan dugaan pelanggaran undang-undang sedang mempraktikkan penegakan norma

b) Pengadilan Banding Amerika Serikat; terdapat dua tujuan pemeriksaan kembali di tingkat banding tersebut. Pertama, untuk mengoreksi kesalahan. Kedua, untuk menyaring dan mengembangkan beberapa perkara yang layak mendapatkan pemeriksaan oleh Mahkamah Agung. Berbeda dengan pengadilan distrik, pengadilan banding biasanya dipertimbangkan oleh tiga orang hakim dalam wilayah tersebut. Pada beberapa pengadilan banding jumlah hakim yang memeriksa perkara bisa bervariasi jumlahnya. Perkara-perkara tertentu yang dianggap penting diperiksa 
bukan oleh majelis, melainkan oleh sebuah sistem yang disebut dengan En Banc, yaitu diperiksa oleh semua hakim banding yang ada di wilayah tersebut.

3) Mahkamah Agung, Mahkamah Agung Amerika Serikat adalah satusatunya pengadilan federal yang disebutkan namanya dalam konstitusi Amerika Serikat, yang menjabarkan secara rinci bentuk-bentuk umum dari yurisdiksi Mahkamah Agung. Para hakim agung dari Mahkamah Agung Amerika Serikat dan serta hakim-hakim distrik, semuanya ditunjuk oleh Presiden Amerika Serikat jika disetujui oleh mayoritas suara dari Senat Amerika Serikat. Para hakim agung dan hakim-hakim lain ini dapat terus mengabdi selama berkelakuan baik yang berlaku, dengan jangka waktu tak terbatas sampai akhir hidup

d. Juri

Terdapat dua tipe juri dalam sistem pengadilan federal, yaitu Juri Agung (grand jury) dan Juri Kecil (petit jurors). Juri Agung merupakan sekelompok pria dan wanita yang dipilih secara acak dari masyarakat awam, yang bertemu untuk menentukan apakah ada sebab yang cukup untuk percaya bahwa seseorang telah melakukan kejahatan federal yang didakwakan kepadanya. Juri Kecil, seperti halnya Juri Agung, dipilih secara acak dari masyarakat untuk mendengar bukti-bukti dan menentukan apakah seorang terdakwa dalam perkara pidana bersalah atau tidak bersalah. ${ }^{12}$

\section{KESIMPULAN}

Penyelenggaraan peradilan pidana di Amerika Serikat dikenal dua model dalam proses pemeriksaan perkara pidana (two models of the criminal process) yaitu due process model dan crime control model. Kedua model di atas, dilandasi oleh adversary model. Sedangkan di Indonesia, dengan melihat penjelasan mengenai tahap pra-adjudikasi maupun adjudikasi, proses peradilan yang ada di Indonesia cenderung kepada model due process model. Struktur penegak hukum yang ada di Amerika dengan di Indonesia secara umum terdapat banyak kesamaan, walaupun tugas pokok dan fungsi masing-masing secara detail terdapat perbedaan. Namun yang jelas berbeda pada sistem peradilan Pidana

12 Ibid. 
Amerika adalah adanya jury yang tidak terdapat pada sistem peradilan pidana di Indonesia. Peranan hakim pada peradilan pidana di Indonesia lebih dominan sebagai pengambil keputusan, sedangkan di Amerika justru jury yang rekrutmennya berasal dari masyarakat.

\section{DAFTAR PUSTAKA}

\section{Buku}

Adjong, Agussalim Andi, 2007, Pemerintahan Daerah Kajian Politik dan Hukum, Ghalia Indonesia, Surabaya.

Hamzah, Andi, 1996, Hukum Acara Pidana di Indonesia, Jakarta: Sapta Artha Jaya.

Ichsan, H. Muchammad dan Susila, M. Endrio, 2006, Hukum Pidana Islam Sebuah Alternatif, Laboratorium Fakultas Hukum UMY, Yogyakarta.

Kristanto, Tri Agus dan Suhanda, Irwan, 2009, Jangan Bunuh KPK: Perlawanan Terhadap Usaha Pemberantasan Korupsi, Penerbit Buku KOMPAS, Jakarta.

Moeljatno, 2000, Asas-asas Hukum Pidana, Rineka Cipta, Jakarta.

Raharjo, Trisno, 2011, Mediasi Pidana dalam Sistem Peradilan Pidana, Mata Padi Pressindo, Yogyakarta.

Sabuan, Ansori, dkk, 1990, Hukum Acara Pidana, Angkasa, Bandung.

Soesilo, R, 1984, Pokok-pokok Hukum Pidana Peraturan Umum dan Delik Khusus, Politea, Bogor.

Sulistia, Teguh dan Zurnetti, Aria, 2012, Hukum Pidana Horizon Baru Pasca Reformasi, Raja Grafindo Persada, Jakarta.

\section{Perundang-undangan}

UU No 8 Tahun 1981 Tentang Kitab Undang-undang Hukum Acara Pidana (KUHAP).

Kitab Undang-undang Hukum Pidana (KUHP).

\section{Sumber Lain}

Attamimi, A. Hamid, 1992, Teori Perundang-Undangan Indonesia, Pidato Pengukuhan Jabatan Guru Besar Tetap Fakultas Hukum Universitas Indonesia.

Hadjon, Philipus M, 1994, Ide Negara Hukum Dalam Sistem Ketatanegaraan Republik Indonesia, Makalah. 
http://wardahcheche.blogspot.co.id/2014/08/hukum-pidana-amerika.html.

http://te-effendi-pidana.blogspot.com/2012/07/sistem-peradilan-pidana-indonesiadan.html.

http://ilmuhukumuin-suka.blogspot.co.id/2013/05/sistem-peradilan-pidanak-diindonesia.html.

https://nasional.sindonews.com/read/1111279/13/mahfud-md-bilang-peradilan-diindonesia-kondisi-kronis-1464151938.

http://sudiknoartikel.blogspot.co.id/2008/03/sistem-peradilan-di-indonesia.html

https://mohammadgie.wordpress.com/2011/12/30/lemahnya-penegakan-hukumdi-indonesia/ .

http://nasional.kompas.com/read/2016/05/25/14101081/mahfud.md.negara.bisa.h ancur.kalau.mafia.peradilan.dibiarkan. 